\title{
PATRIOTISME DALAM SYAIR BITAQAH HAWIYYAH KARYA MAHMUD DARWISY
}

\author{
Muhammad Sayyidul Arwan \\ UIN Sunan Kalijaga Yogyakarta \\ ustadz141995@gmail.com,
}

\author{
Faizetul Ukhrawiyah \\ UIN Sunan Kalijaga Yogyakarta \\ faizahukhrawiyah@gmail.com
}

\begin{abstract}
Poetry is a literary media that is very dense of meaning. Poetry is also a medium for conveying ideas of a poet to be conveyed to the reader. In this paper the author conveyed the explanation of the meaning poem "Bitaqah Hawiyyah" by Mahmud Darwisy using the study of semiotics. In this paper the presentation uses qualitative methods by library research and uses Riffaterre's semiotic theory. The formulation of the problem in this paper is how the form of the unity of meaning structure in the poem "Bitaqah Hawiyyah" by Mahmud Darwisy using Riffaterre's semiotic study. The purpose of this study was to determine the form of the unity of meaning structure in the poem "Bitaqah Hawiyyah" by Mahmud Darwisy using Riffaterre's semiotic study. The result of this research is the form of the unity of meaning structure in the poem "Bitaqah Hawiyyah" by Mahmud Darwisy is Nationalism and Patriotism which manifests in pride, love and maintenance of identity, homeland and ownership.
\end{abstract}

Keywords: Riffatere's semiotic, Bitaqah Hawiyyah, Mahmud Darwisy

\begin{abstract}
ABSTRAK
Puisi merupakan media sastra yang sangat padat akan sebuah makna. Puisi juga sebagai media penyampai ide atau gagasan seorang penyair yang ingin disampaikan pada pembaca. Pada tulisan ini penulis akan menyampaikan paparan pemaknaan puisi "Bitaqah Hawiyyah" karya Mahmud Darwisy dengan menggunakan kajian semiotika. Pada tulisan ini pemaparan menggunakan metode kualitatif dengan cara penelitian pustaka dan memakai teori semiotika Riffaterre. Rumusan masalah pada tulisan ini yaitu bagaimana bentuk kesatuan struktur makna pada puisi "Bitaqah Hawiyyah" karya Mahmud Darwisy dengan menggunakan kajian semiotika Riffaterre. Tujuan penelitian ini adalah mengetahui bentuk kesatuan struktur makna pada puisi "Bitaqah Hawiyyah" karya Mahmud Darwisy dengan menggunakan kajian semiotika Riffaterre. Hasil dari penelitian ini adalah bentuk kesatuan struktur makna pada puisi puisi "Bitaqah Hawiyyah" karya Mahmud Darwisy yaitu Nasionalisme dan Patriotisme yang terwujud pada kebanggaan, kecintaan dan pemertahanan pada identitas, tanah air dan kepemilikan.
\end{abstract}

Kata kunci: semiotik Riffaterre, Bitaqah Hawiyyah, Mahmud Darwisy

\section{PENDAHULUAN}

Puisi merupakan bagian dari karya sastra yang menjadi sebuah genre karya sastra tersendiri yang bermediumkan bahasa serta menggunakan istrumen-istrumen bahasa untuk memberikan 
nilai keindahan pada sebuah karya sastra. Puisi dijadikan sebagai sarana pengungkapan ide, gagasan dan emosi penulis dengan bentuk yang berbeda dengan tujuan yang sama, yaitu untuk menyampaikan sebuah pesan seorang penulis. Unsur pada sebuah puisi ada dua hal, yaitu unsur batin seperti tema, rasa, nada dan amanat, dan struktural fisik, yaitu perwujudan sebuah puisi sebagai hasil sebuah karya seni (Miranti, 2018:30). Sebagai salah satu genre sastra, puisi memiliki banyak kelebihan dari genre sastra lainnya seperti prosa dan drama. Salah satu kelebihan puisi yaitu terdapat dalam keindahan kata-kata yang dirangkai sedemikian rupa dan menghasilkan sebuah musikalisasi yang indah dan nyaman untuk dinikmati oleh para pembaca dan pendengarnya (Quthub, 1980: 53). Seperti sebuah puisi yang berjudul "Bitaqah Hawiyyah".

Puisi "Bitaqah Hawiyyah" merupakan salah satu puisi bebas Arab yang ditulis oleh Mahmud Darwisy seorang penyair Palestina. Puisi bebas Arab merupakan puisi yang tidak terikat prosodi atau matra gaya lama atau arud dan qafiyah, yang secara bentuk terkadang mendekati gaya prosa sastra dan enjambemen-nya tidak dalam bentuk qasidah (dua baris sejajar), tetapi tersusun ke bawah (Kamil, 2009: 16). Puisi tersebut mengisahkan tentang perjuangan rakyat Palestina melawan penjajah negara Israel yang merebut wilayah negara Palestina (Ni'mah, 2017: 96). Puisi itu diterbitkan pada tahun 1964. Para tentara Israel merebut semua yang dimiliki oleh Palestina, wilayahnya, aset-asetnya, ekonominya, dan sampai pada perebutan rumah-rumah rakyat Palestina. Dengan terjadinya peristiwa tersebut Mahmud Darwisy membuat sebuah puisi yang menggambarkan diri mereka dengan sebuah puisi yang berjudul "Bitaqah Hawiyyah" yang berarti "Kartu Identitas".

Mahmud Darwisy menggunakan puisi sebagai media penyampaian ide dan gagasannya. Puisi merupakan salah satu media kesusastraan yang singkat dengan adanya pemadatan isi dan makna yang dituangkan secara tersirat dengan menggunakan kata kias dan penuh dengan imajinatif (Marantin, 2018: 29). Dengan kepadatan sebuah puisi pembaca akan memunculkan berbagai pemaknaan terhadap puisi tersebut. Penggunaan kata kiasan dalam puisi sering kali membuat para pembacanya mengalami kesulitan dalam memahami isi dan makna pada puisi tersebut. Sehingga dengan perbedaan latar belakang pembaca akan mempengaruhi pemaknaan puisi dan akan banyak memunculkan pemaknaan yang beragam.

Adanya kepadatan kata yang mengandung sebuah isi dan makna, memerlukan adanya sebuah cara pemaknaan, sehingga makna yang diinginkan seorang pengarang sampai kepada pembaca. Salah satu cara pemaknaan sebuah puisi yaitu menggunakan metode semiotika. Sebuah puisi menggunakan bahasa sebagai medianya, dan bahasa sejatinya merupakan sistem semiotika atau ketandaan yang bermakna. Maka pemaknaan sebuah puisi erat dengan semiotika. Salah satu ahli semiotika yang terfokus pada penelahan makna puisi yaitu Michael Riffaterre.

Semiotika menurut Kamus Besar Bahasa Indonesia ("KBBI Daring”, 2016) adalah segala sesuatu yang berhubungan dengan sistem tanda dan lambang dalam kehidupan manusia. Menurut Premiger (dalam Pradopo, 1999:76), semiotika merupakan ilmu tentang tanda, mempelajari fenomena sosial dan budaya, termasuk sastra sebagai sistem tanda. Pembacaan puisi dengan teori semiotika sangat sesuai dengan menggunakan teori semiotika Riffaterre. 
Ratih (2016: 5) menjelaskan bahwa semiotika yang dikemukakan oleh Riffaterre menggunakan metode pemaknaan secara khusus, yaitu dengan memberi makna karya sastra sebagai sistem tanda-tanda, berarti sebuah karya sastra memproduksi makna tanda-tanda. Riffaterre (dalam Ratih, 2016: 5) menjelaskan puisi merupakan aktivitas bahasa yang berbeda dengan pemakaian bahasa pada umumnya. Puisi berbicara suatu hal dengan cara tidak langsung, yaitu dengan menyembunyikan makna dalam sebuah tanda. Dan semiotika Riffaterre membahas semua hal tersebut, sehingga semiotika Riffaterre paling tepat digunakan untuk menganalisis sebuah puisi untuk mendapatkan makna puisi tersebut.

Pemilihan objek formal pada tulisan ini yaitu semiotika Riffaterre, karena teori ini sangat tepat untuk menjadi alat untuk menganalisis sebuah karya sastra puisi. Dan objek material pada tulisan ini yaitu Puisi "Bitaqah Hawiyyah" karya Mahmud Darwisy. Pemilihan objek material tulisan ini karena puisi ini memenuhi kriteria dalil sastra menurut J. Elema (dalam Pradopo, 1997: 56) yaitu a) puisi bernilai seni jika pengalaman jiwa yang menjadi dasar dalam kata; b) pengalaman jiwa semakain tinggi bila meliputi keutuhan jiwa; c) pengalaman jiwa semakain tinggi bila pengalam itu makin kuat; d) pengalaman jiwa semakain tinggi bila isi pengalaman itu semakin luas.

Dalam tulisan ini akan mengkaji masalah dan menjawabnya dengan rumusan masalah, yaitu: bagaimana bentuk kesatuan struktur makna yang terkandung dalam Puisi "Bitaqah Hawiyyah" karya Mahmud Darwisy dengan menggunakan kacamata teori semiotika Reffaterre.

\section{METODE}

Metode adalah instrumen yang digunakan oleh peneliti untuk mengumpulkan data. Metode adalah cara kerja untuk dapat memahami fokus kajian yang menjadi sasaran dari ilmu yang bersangkutan (Soehada, 2012: 63).

Penelitian ini adalah penelitian pustaka dengan menerapkan metode kualitatif. Teknik penulisan adalah deskriptif kualitatif, yang memaparkan pembahasan berdasarkan karya sastra. Ratna (2008: 47) menyatakan bahwa metode kualitatif memberikan perhatian terhadap data alamiah dalam hubungannya dengan konteks keberadaannya. Dalam hal ini, data alamiah yang dimaksud adalah teks sastra berupa Puisi "Bitaqah Hawiyyah” karya Mahmud Darwisy.

Untuk menganalisis masalah yang ada, langkah-langkah penelitian yang dilakukan penulis adalah:

1. Melakukan pembacaan heuristik dan hermeneutik pada Puisi "Bitaqah Hawiyyah" karya Mahmud Darwisy;

2. Mencari matriks, model, dan varian Puisi "Bitaqah Hawiyyah" karya Mahmud Darwisy;

3. Mencari hipogram yang ada pada Puisi "Bitaqah Hawiyyah" karya Mahmud Darwisy;

4. Menarik simpulan dari data-data yang diperoleh. 


\section{PEMBAHASAN}

Riffaterre (1978:1) menyatakan, faktor pembeda antara puisi dan non puisi adalah cara sebuah teks puisi yang membawakan makna. Dalam buku Semiotics of Poetry karya Reffaterre (1978:13-15), ada empat hal yang penting dalam pemaknaan karya sastra, yaitu; a) puisi diekspresikan tidak langsung; b) pembacaan heuristik dan pembacaan retrokatif atau hermenetik, c) maktriks, model dan varian-varian; dan d) hiprogam.

Ketidaklangsungan menurut Riffaterre (1978:2) disebabkan oleh tiga hal, yaitu penggantian atau pergeseran makna (displacing of meaning), perusakan atau penyimpangan makna (distorting of meaning), dan penciptaan makna (creating of meaning). Penggantian atau pergeseran arti terjadi ketika sebuah tanda mengalami perubahan makna satu ke makna lain, hal tersebut disebabkan oleh penggunaan bahasa kiasan. Perusakan atau penyimpangan makna disebabkan karena terjadinya ambiguitas, kontradiksi dan nonsen. Dan penciptaan makna merupakan pemaknaan segala hal yang di dalam bahasa tidak bermakna, seperti simetris, rima, ekuivalensi makna antara posisi homologues.

Menurut Reffaterre (1978:4-5) memahami semiotika puisi yaitu dengan dua level atau tingkat pembacaan, level pertama yaitu pembacaan heuristic dan level kedua yaitu pembacaan retrokatif atau hermenetik. Pembacaan heuristik adalah pembacaan menurut sistem bahasa, yaitu dibaca berdasarkan tata bahasa normatif, morfologi, semantik, dan sintaksis, ini merupakan bentuk pembacaan semiotik pada tingkat pertama. Menurut Riffaterre (1978), pembacaan heuristik merupakan pembacaan tingkat pertama untuk memahami makna secara linguistik. Pada pembacaan hermeneutik, pembaca mulai mengaplikasikan kode sastra dan kode budaya yang diketahui untuk menelaah maknanya. Pembacaan pada tingkat ini masih mengikuti arti denotatif (arti dalam kamus) sehingga masih banyak ditemukan ketidakgramatikalannya. Pembacaan baru menemukan makna pada proses pembacaan tingkat kedua, dalam arti bahwa pembacaan dilakukan secara berulangulang (retroaktif) atau berdasarkan sistem semiotik tingkat kedua (konvensi sastra) untuk memperoleh daya interpretasi yang baik dalam mengungkapkan makna dari bahasa puisi yang lebih luas. Pada pembacaan tahap kedua, pembaca diarahkan pada pemahaman bahwa teks berawal dari adanya matriks (Riffaterre, 1978:5-6).

Teks berawal dari adanya matriks (Riffaterre, 1978:12). Matriks adalah kata kunci yang memberikan makna kesatuan sebuah puisi. Matriks yang berupa suatu tuturan minimal dan harfiah (kata, frasa, klausa, atau kalimat sederhana) selanjutnya ditransformasikan menjadi parafrasa yang lebih panjang, kompleks, dan tidak harfiah, yaitu keseluruhan puisi. Model tersebut berupa satu kata atau kalimat yang bersifat puitis dan bentuk variannya yang akan ditentukan. Varian-varian tersebut bisa dikatakan sebagai penjabaran model yang terdapat pada setiap bait atau baris puisi.

Jenis hipogram dibagi menjadi dua macam, yaitu hipogram potensial dan hipogram aktual (Riffaterre, 1978:23). Hipogram potensial tidak terdapat di dalam teks, tetapi harus diabstraksikan dari teks. Hipogram potensial ialah matriks, dapat berupa satu kata, frasa, atau kalimat. Hipogram potensial terwujud dalam segala bentuk aplikasi makna kebahasaan, baik 
Volume 6 Nomor 2 Tahun 2019 eISSN : $25494155-$ pISSN $: 23557083$

yang berupa presuposisi maupun sistem deskriptif atau kelompok asosiasi konvensional. Hipogram aktual dapat berupa teks nyata, kata, kalimat, peribahasa, atau seluruh teks. Hipogram aktual terwujud dalam teks-teks yang ada sebelumnya baik berupa mitos maupun karya sastra lainnya.

\section{Makna Bitaqah Hawiyyah Karya Mahmud Darwisy}

Bunyi teks puisi "Bitaqah Hawiyyah” karya Mahmud Darwisy sebagai berikut:

$$
\begin{aligned}
& \text { سجّل } \\
& \text { أنا عربي } \\
& \text { ورقم بطاقتي خمسون ألف } \\
& \text { وأطفالي ثمانية } \\
& \text { وتاسعهم ... سيأتي بعد صيف ! } \\
& \text { فهل تغضب ؟ }
\end{aligned}
$$

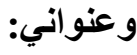

$$
\begin{aligned}
& \text { أنا من قريتي عزلاء منسيه } \\
& \text { شوارعها بلا أسماء } \\
& \text { وكل رجالها في الحقل والمحجر } \\
& \text { فهل تغضب؟ }
\end{aligned}
$$

$$
\begin{aligned}
& \text { سجل .. برأس الصفحة الأولى } \\
& \text { أنا لا أكره الناس } \\
& \text { ولا أسطو على أحد } \\
& \text { ولكنّي .. إذا ما جعت } \\
& \text { آكل لحم مغتصبي } \\
& \text { حذار .. حذار .. من جوعي } \\
& \text { ومن غضبي }
\end{aligned}
$$




\author{
Sajjil \\ Ana 'Arabi> \\ Wa raqmu bit $\{a>q a t i>k h a m s u>n a$ alafin \\ Wa at $f f a>l i>s \mid a m a>$ niyah \\ Wa ta $>$ si'ahum ... saya'ti> ba'da s\}aifin ! \\ Fahal taghd\}ab? \\ Wa 'unwa>ni> : \\ Ana> min qaryatin 'azla $>$ a mansiyyah \\ Syawa $>$ ri'uha $>$ bila $>$ asma $>$ in
}

Wa kullu rija>liha> fi al-haqli wa al-mahjari

Fahal taghd\}ab?

Sajjil... bira'si as-s\}afhah al-ula>

Ana> la $>$ akrahu an-na>s

Wa la $>$ ast $\}$ u $>$ 'ala ahadin

Wala $>$ kinni $>\ldots i d z \mid a>m a>j u ' t u$

A $<$ kulu lahma mughtas\}abi >

$\left.\operatorname{Haz}_{3} a>\operatorname{ri} \ldots h a z\right\} a>r i \ldots \min j u>{ }^{\prime} i>$

Wa min ghad\}abi>

\title{
Analisis Pembacaan Heuristik
}

Pembacaan heuristik merupakan pembacaan level pertama, yaitu pembacaan menurut sistem bahasa, yaitu dibaca berdasarkan tata bahasa normatif, morfologi, semantik, dan sintaksis.

Kalimat pertama pada puisi tersebut adalah سجّل yang terdiri dari satu kata. Kalimat tersebut merupakan kalimat yang berbentuk perintah. Arti kalimat tersebut adalah “catat!". 
Kalimat selanjutnya yaitu أنا عربي Sabjeknya yaitu kata أنا عati "aku”, yaitu orang pertama tunggal. Dan predikatnya yaitu kata عربي yang berarti “orang arab”.

adalah "kartu identitasku”. kata tersebut berbentuk

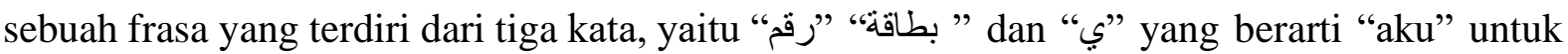

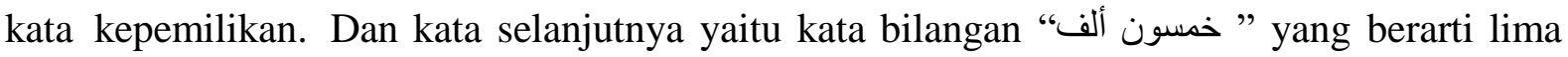
puluh ribu.

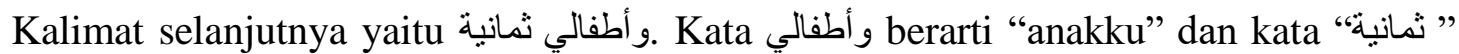
berarti delapan.

. Kata تاسعهم berarti "kesembilanny”, maksud dari kata

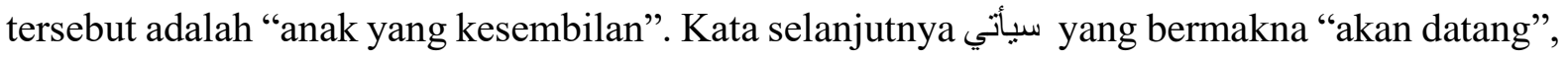
kata tersebut terdiri dari dua bagian yaitu "يأتي" yang diberi tambahan " "س" pada awal kata atau awal dari fiil mudhori', yaitu kata kerja yang baru berlangsung atau yang akan berlangsung. Akan tetapi kata tersebut diartikan "lahir" karena yang akan datang adalah seorang anak yang kesembilan. Kata صيف berarti musim panas.

Kalimat terakhir pada bagian awal yaitu تغضب yaitu "kamu marah". Kata tersebut berbentuk kata kerja atau fiil mudhori'. Pelaku dari kata tersebut yang tersimpan di kata tersebut adalah "kamu laki-laki tunggal".

Kalimat pertama pada bagian kedua adalah عنواني. Kalimat tersebut berbentuk frasa yang terdiri dari dua kata "عنوان" yang berarti "alamat" dan "ب yang berarti "aku" yang berbentuk kepemilikan. Sehingga arti pada frasa tersebut adalah "alamatku".

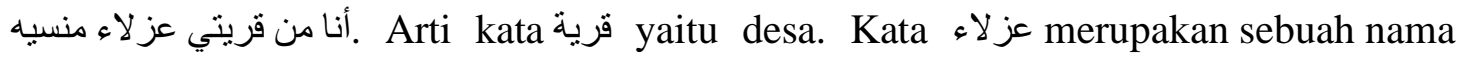

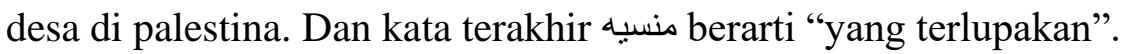

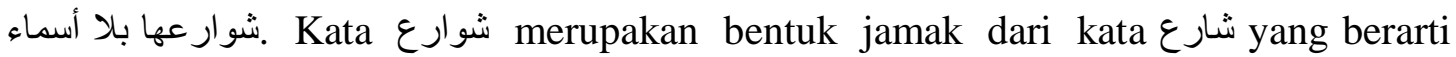

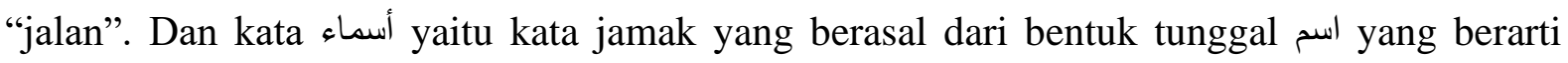
"nama".

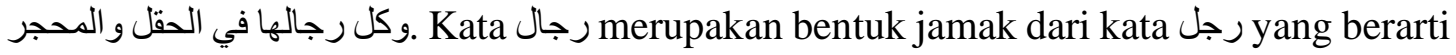

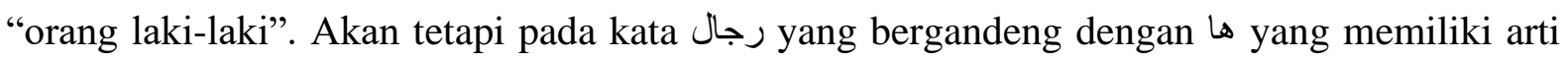
kembali ke kata قرية yaitu desa, maka kata رجال رجال berarti penduduk. Kata الحقل هال memiliki arti ladang dan المحجر berarti tempat penambangan batu. Dua kata tersebut menunjukkan suatu tempat.

Kalimat فهل تغضب merupakan kalimat penutup padabagian kedua ini. Kalimat ini seperti halnya kalimat penutup pada bagian pertama. Arti kata تغضب yaitu "kamu marah". Kata tersebut berbentuk kata kerja atau fiil mudhori'. Pelaku dari kata tersebut yang tersimpan di kata tersebut adalah "kamu laki-laki tunggal".

merupakan kata seperti kata pertama dalam puisi ini. Kalimat tersebut merupakan kalimat yang berbentuk perintah. Arti kalimat tersebut adalah 
“catat !". Pada kata ini sebagai penegas lagi dari kata pada awal puisi ini. Dan pada kalimat ini diberi penekanan yaitu dengan frasa رأس الصفحة الأولى yang berarti “di bagian atas halaman pertama". Kalimat tersebut menjadi kalimat pertama pada bagian ketiga dalam puisi ini, dan sebagai penegas dari kalimat pertama pada bagian pertama puisi.

. Kata أنا لا أكره الناس

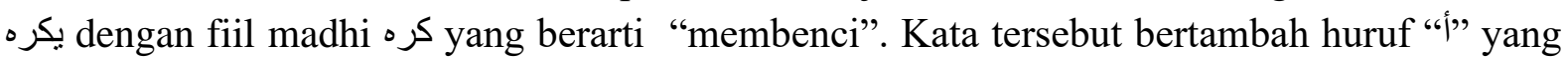
menunjukkan arti "saya" atau pelaku pertama tunggal.

merupakan kata kerja atau fiil mudhori’ dengan kata asal dari dengan fiil madhi سطط yang berarti "menyerang atau mengganggu". Kata tersebut bertambah huruf “|l” yang menunjukkan arti "saya" atau pelaku pertama tunggal.

جentuk kata kerja lampau yaitu fiil madhi dengan tambahan $\underbrace{\prime}$ yang menunjukkan pelaku pertama tunggal. Kata tersebut bermakna “aku lapar”.

أكل merupakan kata kerja atau fiil mudhori’ dengan kata asal dari آكل Kata . آكل لحم مغتصبي dengan fiil madhi يأكل yang berarti “menyerang atau mengganggu”. Kata tersebut bertambah huruf "ا” dari huruf "I)" yang dobel, yang menunjukkan arti "saya" atau pelaku pertama tunggal. Arti kata مغتصبي yaitu "daging, dan arti kata مغتصب yaitu dari لحم "yang berarti “yang meramas atau perampas, pemeras, pemaksa".

arti kata tersebut adalah hati-hati. Kata tersebut diulang

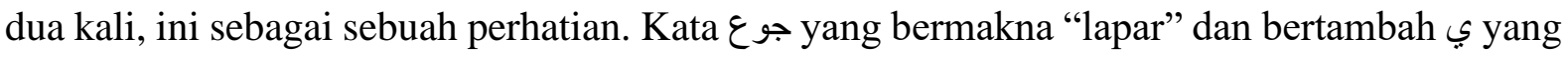
bermakna "aku" dengan fungsi kepemilikan.

غضب yang berarti “marah atau kemarahan". Dan kata tersebut ditambah dengan ي yang bermakna "aku" dengan fungsi kepemilikan.

Hasil pengartian puisi "Bitaqah Hawiyyah" karya Mahmud Darwisy dengan pembacaan Heuristik.

\section{Catat!}

Aku merupakan orang Arab

Dan nomer identitasku lima puluh ribu Aku mempunyai delapan anak

Dan yang kesembilan, akan lahir setelah musim panas!

Apakah kau akan marah?

Alamatku:

Aku dari desa Azla yang terlupakan Jalan-jalannya tampa nama 
Dan seluruh penduduknya berada di ladang dan berada di tempat penambangan batu

Akankah engaku akan marah?

Catatlah! .. pada bagian atas halaman pertama

Aku tak akan membenci orang-orang

Dan aku tak akan juga mengganggun seorang pun

Akan tetapi .. Jika aku lapar

Aku akan makan daging para perampas

Hati-hati.. hati-hati.. dari kelaparanku

Dan juga kemarahanku

Arti heuristik pada puisi "Bitaqah Hawiyyah" karya Mahmud Darwisy adalah arti secara tataran bahasa. Pembacaan tersebut belum masuk pada tataran makna secara utuh menjadi satu kesatuan makna dalam puisi. Walaupun pada pembacaan pertama sudah dapat dipahami secara arti teks, untuk menjadi batu pijakan pada pembacaan kedua yang akan menampilkan pemaknaan teks secara keseluruhan.

\section{Pembacaan Hermeneutik}

Sebagaimana yang telah dipaparkan dalam teori semiotika Riffatterre di atas, bahwa dalam mendapatkan makna yang menyeluruh harus melalui dua pembacaan. Pembacaan tingkat pertama yaitu heruistik yang belum mendapakan pemaknaan puisi secara utuh, dan hanya pada tataran bahasa, belum pada tataran sastra. Dengan pembacaan kedua yaitu pembacaan hermenetik akan mendapatkan pemahaman secara utuh dalam pengambil makna puisi yang akan dianalisis. Oleh karena itu pembacaan kedua, pembacaan hermenetik menjadi pentik untuk mendapatkan kesatuan struktur makna puisi tersebut.

Pembacaan hermenatik juga dilakukan secara struktural. Menurut Riffatterre (dalam Latifi, 2013:44) pembacaan hermenetik dilakukan secara berbolak balik dari bagian ke keseluruhan dan kembali ke bagian dan seterusnya secara struktural dan berulang. Pembacaan setiap bait diulang-ulang dan diulas kembali, sehingga dapat direvisi, dan dilanjutkan pada bait selanjutnya secara teratur dan berulang-ulang. Dan ketika mendapatkan pembacaan dari bagian sebelumnya, kemudian dimasukkan pada pembacaan kepada bagian setelahnya, sehingga mendapatkan kesatuan struktural makna dalam sebuah puisi.

Puisi puisi "Bitaqah Hawiyyah" karya Mahmud Darwisy memiliki tiga bagian makna yang berbeda. Bagian pertama penulis mengungkapkan kata pertama yaitu سجّل yang berarti "Catat!" dengan menggunakan bentuk perintah dan sebuah seruan. Kata tersebut menunjukkan 
أنا عربي akan adanya hal yang penting yang akan dismpaikan. Dan kalimat selanjutnya yaitu bermakna "Aku merupakan orang Arab". Dalam kalimat tersebut penulis menyatakan bahwa dia adalah orang arab. Hal tersebut menunjukkan kebanggaan dia menjadi orang arab, ditunjukkan dengan pengakuan dan diawali dengan kalimah pertama yang mengintruksikan untuk mencatat sebagai penegasan hal yang penting. Kalimat selanjutnya yaitu ورقم بطاقتي خمسون ألف yang berarti "Dan nomer identitasku lima puluh ribu". Tidak hanya ia mengemukakan bahwa ia orang arab, akan tetapi ia juga melontarkan nomor identitas ia dalam masyarakat arab. Dan dipertegas identitas ia sebagai orang arab dengan karakter orang arab,

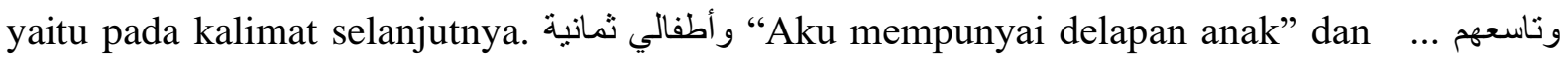
"Dan yang kesembilan, akan lahir setelah musim panas!”, kalimat tersebut menunjukkan kebanggaan berkarakter arab yaitu dengan memiliki banyak anak. Kalimatkalimat tersebut ditegaskan kepada orang non-arab yang tidak suka dengan arab. Hal tersebut di munculkan pada kalimat terakhir pada bagian awal yaitu فهل تغضب "Apakah kau akan marah?". Kalimat tersebut menegaskan dan menjelaskan kepada kalimat pertama yang berbentuk perintah untuk mencatat bahwa dirinya adalah orang arab yang bangga dengan kearabanya. Kebanggaan tersebut berada pada penjelasan identitas dan karakter orang arab. Dan ditutup dengan sebuah pertanyaan yang bermaksud menantang kepada orang yang tidak suka orang arab.

Bagian kedua dalam puisi ini menjelaskan tentang daerah tempat tinggal tokoh pada puisi tersebut. Kaliamat awal pada bagian ini disambut dengan kata-kata عنو "Alamatku:", kalimat tersebut menunjukkan lokasi dia atau daerah dia berada dimana. Dan dilanjutkan pada kalimat selanjutnya yaitu أنا من قريتي عز لاء منسيه “Aku dari desa Azla yang terlupakan”. Ia berada pada sebuah daerah yang terlupakan. Hal ini berarti bahwa daerah ia sangat terisolasi atau sangat pedesaan sehingga orang pun melupakan daerah tersebut. hal tersebut diperjelas dengan

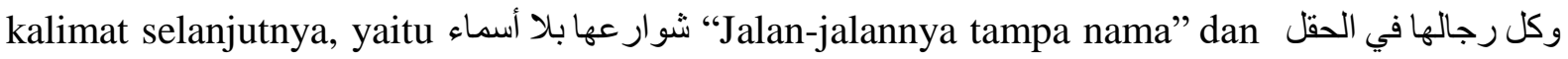
"Dan seluruh penduduknya berada di ladang dan berada di tempat penambangan batu". Gambaran desa seorang tokoh pada puisi tersebut, yaitu berada didesa yang terlupakan atau tidak dikenal oleh orang lain. Kondisi desanya secara intrastruktur sangat kurang, hal tersebut dikatakan dengan tidak adanya nama-nama pada jalan-jalan di desa tersebut. Serta kondisi ekonomi mereka yaitu menjadi para petani yang berladang dan para buruh pada penambangan batu. Pada bagian ini, seorang penulis menggambarkan tentang kondisi sebuah daerah dalam bidang infrastruktur serta sosial ekonomi masyarakat. Bagian ini ditutup dengan kalimat في "Akankah engaku akan marah?”. Kalimat tersebut penegas atas kebanggan tokoh pada puisi tersebut, walaupun kondisi daerah yang begitu rupa. Dengan kebanggaan tersebut, ia menutup bagian dengan sebuah pertanyaan yang bertujuan untuk menyindir kepada orang-orang yang tidak suka dengan kondisi daerah tersebut.

Bagian terakhir pada puisi ini memaparkan tentang sikap ia terhadap orang yang tidak menyukai arab. Pada bagian ini penulis menegaskan lagi dan lebih keras lagi untuk memperhatikan perkataan ia. Kalimat pertama yaitu atatlah! .. pada bagian atas halaman pertama", kalimat tersebut merupakan bentuk keserius ia dalam perkataan ia. Sehingga perkataannya harus menjadi perhatian bagi orang-orang yang tidak suka pada arab. Setelah itu ia mengungkapkan sikap ia pada orang, hal tersebut tertuang pada أنا لا أكره 
"Aku tak akan membenci orang-orang” dan و لا أسطو على أحد "Dan aku tak akan juga mengganggun seorang pun”. Karakter pada perkataan tersebut adalah ia tidak tipe orang yang membenci dan mengganggu orang lain. hal tersebut menunjukkan karakter yang baik dalam sosial. Akan tetapi karakter baik tersebut dapat berubah ketika ia dalam kondisi yang tidak baik. Hal tersebut dapat dilihat pada kaliamat ولكنّي .. إذا ما جعت "Akan tetapi Jika aku lapar" dan Aku akan makan daging para perampas”. Kalimat tersebut menunjukkan jika ia dalam kondisi lapar, maka ia akan memakan daging pada perampas. Maksudnya ketika ia mengalami kondisi yang serba kekurangan, kondisi yang tidak baik yang diakibatkan oleh perampasan, pengeksploitasian. Maka siakap ia dalam kondisi tersebut mengharuskan untuk memakan daging perampas. Memakan daging para perampas berarti melakukan perlawanan dan pembantaian kepada para perampas segala sesuatu milik mereka. Dengan perubahan sikap itu, tokoh memberikan peringatan kepada para perampas untuk berhati-hati pada diri mereka. Hal tersebut tertuang pada kalimat حذار .. حذار .. من جوعي "Hati-hati.. hati-hati.. dari kelaparanku" dan ومن غضبي "Dan juga kemarahanku”.

\section{Matrik, Model, Varian}

Matrik merupakan kata kunci pada sebuh puisi sehingga matrik ini mengarah pada sebuah tema pada sebuah puisi. Matrik merupakan pemersatu makna pada sebuah puisi. Sebelum matrik, perlu adanya model, yaitu tanda yang monumental dari puisi itu yang dihadirkan secara tekstual. Dan model didukung oleh varian-varian pada puisi tersebut. Varian-varian tersebut bisa dikatakan sebagai penjabaran model yang terdapat pada setiap bait atau baris puisi.

Model pada puisi "Bitaqah Hawiyyah" karya Mahmud Darwisy pada bagian pertama

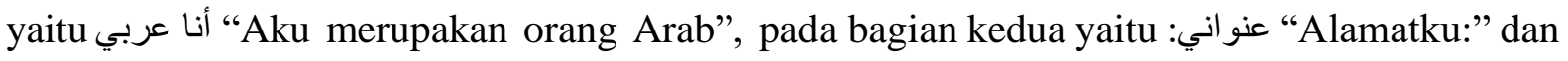
pada bagian ketiga yaitu آكل لحم مغتصبي "Aku akan makan daging para perampas”. Dengan tiga model tersebut menunjukkan tiga hal yang inti pada setiap bagian puisi. Model pertama yaitu “Aku merupakan orang Arab”, pada model ini menunjukkan kebanggaan menjadi orang arab. Hal ini didukung oleh varian-varian atau data pendukung dengan kalimat-kalimat setelah model tersebut. Kalimat-kalimat pada bagian ini menunjukkan tentang kebanggaan identitas dan kebanggaan dengan karakter sebuah identitas.

Model pada bagian kedua yaitu cAlamatku:”. Model tersebut didukung oleh varian-varian yang terpapar pada kaliamt-kalimat puisi selanjutnya. Model pada bagian ini diperkuat dengan varian yang menunjukkan kondisi daerah. Penggambaran kondisi daerah tersebut terlihat dari kondisi infrastruktur dan sosial ekonomi. Akan tetapi dalam bagian ini, sebuah daerh menjadi sebuah kebanggan bagi tokoh.

Bagian ketiga yaitu yaitu آكل لحم مغتصبي “Aku akan makan daging para perampas”, kalimat tersebut sebagai model. Varian yang mendukung model itu terdapat pada kalimat sebelum dan sesudahnya. Seorang tokoh akan berubah karakternya yang baik menjadi keras. Perubahan karakter tokoh diakibatkan, jika tokoh mengalami kondisi yang tidak nyama. Maka ia akan memakan daging perampas, dengan maksud akan memperjuangkan milik mereka yang telah dirampas. 
Dengan tiga model dapat diambil sebuah matrik yaitu bagian pertama, menerangkan tentang kebanggan identitas; bagian kedua menerangkan tentang; kecintaan pada daerah; dan bagian ketiga menerangkan tentang pemertahan kepemilikan. Hubungan tigal hal tersebut dapat disimpulkan dengan adanya matrik, yaitu kebanggaan, kecintaan dan pemertahanan pada identitas, tanah air dan kepemilikan.

\section{Hipogram}

Hipogram dibagi menjadi dua macam, yaitu hipogram potensial dan hipogram aktual (Riffaterre, 1978:23). Hipogram potensial tidak terdapat di dalam teks, tetapi harus diabstraksikan dari teks. Hipogram potensial ialah matriks, dapat berupa satu kata, frasa, atau kalimat. Hipogram aktual dapat berupa teks nyata, kata, kalimat, peribahasa, atau seluruh teks yang terwujud dalam teks-teks yang ada sebelumnya baik berupa mitos maupun karya sastra lainnya.

Hiprogam potensial pada puisi "Bitaqah Hawiyyah" karya Mahmud Darwisy adalah sebuah kesimpulan dari matriks yaitu kebanggaan, kecintaan dan pemertahanan pada identitas, tanah air dan kepemilikan. Dan bentuk hiprogam aktual yaitu kebanggaan, kecintaan dan pemertahanan pada identitas, tanah air dan kepemilikan terhimpun pada sifat Nasionalisme dan Patriotisme. Nasionalisme dan Patriotisme merupakan kecintaan pada tanah air. Hal ini menggambarkan tentang sikap para orang arab terhadap bangsa dan negaranya, terutama masyarakat Palestina. Perjuangan masyarakat palestina terhadap perlawanan kepada Israel yang merebut hak milik mereka.

\section{KESIMPULAN}

Teori semiotik Riffaterre merupakan salah satu teori penggalian makna yang tekandung dalam puisi. Melalui dua cara kerja teori ini yang mendasarkan pada dua level pembacaan yakni heuristik dan hermeneutic, kita dapat menemukan ketidaklangsungan ekspresi dan kesatuan makna yang tersembunyi di balik bingkai susunan kata-kata sebuah puisi.

Puisi "Bitaqah Hawiyyah" yang memiliki arti "Kartu Identitas" masih memiliki makna yang kabur dan belum menemukan keutuhan makna di dalamnya jika kita hanya melakukan pembacaan pada tingkat pertama, yakni pembacaan heuristik. Melalui pembacaan pada level kedua, yakni pembacaan hermeneutik, kita dapat menemukan keutuhan makna yang tersirat di dalam puisi "Bitaqah Hawiyyah". Bentuk kesatuan struktur makna pada puisi puisi "Bitaqah Hawiyyah" karya Mahmud Darwisy yaitu Nasionalisme dan Patriotisme yang terwujud pada kebanggaan, kecintaan dan pemertahanan pada identitas, tanah air dan kepemilikan. Makna ini sejalan dengan bentuk kondisi pada negara Palestina yang memperjuangkan keutuhan negara mereka yang telah dijajah oleh Israel.

\section{DAFTAR PUSTAKA}

Al-Ayubi, Yasin, Madzahib Al-Adab Ma'alimu wa In'ikaasaat, (Beirut: Al-Muassasah AlJami'ah Li Ad-Diraasaat wa At-Tauzi', 1982). 


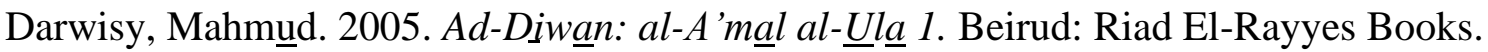

Kamil, Sukron. 2009. Teori Kritik Sastra Arab: Klasik dan Modern. Jakarta: Rajawali Pers.

KBBI Daring. 2016. Diakses melalui https://kbbi.kemdikbud.go.id/entri/semiotika.

Latifi, Yulia Nasrul. 2013. Puisi Ana Karya Nazik al-Mala ’ikah. Adabiyyat, Vol XII.

Marantin, Azka. 2018. Analisis Makna Heuristik Dan Hermeunitik Teks Puisi Dalam Buku Syair-Syair Cinta Karya Khalil Gibran. Caraka : Jurnal Pendidikan Bahasa dan Sastra Indonesia serta Bahasa Daerah, Volume 7.

Ni'mah, Evayatun. 2017. Pandangan Nasionalisme Dalam Puisi Mahmud Darwisy dan Rendra Dalam Analisis Sastra Banding. An-Nas: Junal Humaniora, Volum 2.

Pradopo, R. D. 1997. Prinsip-prinsip Kritik Sastra. Yogyakarta: UGM Press.

Pradopo, R. D. 1999. Semiotika: Teori, Metode dan Penerapannya dalam Pemaknaan Sastra. Humaniora.

Quthub, Sayyid. An-Naqd al-Adabi: Usuluhu wa Manahijuhu. Kairo: Daar asy-Suruq. 1980.

Ratih, Rina. 2016. Teori dan Aplikasi Semiotik Michael Riffaterre. Yogyakarta: Pustaka Pelajar.

Ratna, Nyoman Kutha. 2008. Teori, Metode, dan Teknik Penelitian Sastra. Yogyakarta: Pustaka Pelajar.

Riffaterre, M. 1978. Semiotics of Poetry. Bloomington: Indiana University.

Soehadha, Moh. 2012. Metode Penelitian Sosial Kualitatif. Yogyakarta: SUKA Press. 